\title{
Recasting the Macroeconomic Policy-making System in Europe
}

by David Vines

\section{Introduction}

The macroeconomic policy-making system in Europe is in profound crisis. The conventional view is that there were clear rules in place, and clear understandings, and that what went wrong was that the rules were flouted and the understandings were not properly respected. I claim that this conventional wisdom is mistaken. In my opinion, the crisis is a direct consequence of the inappropriate policy-making system which was adopted when the Euro was established twelve years ago.

It is widely agreed that solving the current crisis in Europe will require immediate action of four kinds: recapitalisation of European banks, Europe-wide fiscal support for the lender-of last-resort activities of the ECB, immediate strengthening of the EFSF so that it can manage Europe's sovereign debt crisis, and a much closer integration of fiscal policies amongst the Eurozone nations. Such changes will be difficult; their implementation is a race against time. I will consider these serious issues in my conclusion but will not discuss them in the body of this contribution.

Instead, I will argue that, in addition to these four actions, the Stability and Growth Pact, or SGP, must be replaced. What is now required in the Eurozone is a stability-oriented fiscal-policy framework for the Euro-zone countries, one which is directed towards the moderation of external imbalances within the Eurozone.

This contribution was written during a Visiting Professorship in the Economics Department at MIT and has been presented at a Policy Seminar of the PEGGED Research Programme, on "Economic Governance in Europe and the World: Immediate Policy Issues", held at the Fondation Universitaire in Brussels on 11 October 2011. I am grateful to Martin Larch from the European Commission for written comments on the paper, for many other comments from those at this meeting, and for detailed suggestions from Christopher Allsopp, Andrew Graham, Vijay Joshi, Andre Sapir, and Max Watson. 
This claim is not new: the lack of a fiscal-policy system of this kind within EMU was a major analytical reason why the UK refused to join EMU. ${ }^{1}$ But it is now very urgent. I maintain that the four actions enumerated in the previous paragraph are bound to fail unless they are also accompanied by the stability-oriented framework for fiscal policy which is described in this article.

This new stability-oriented fiscal-policy framework is outlined in a paper by Christopher Allsopp and me which appeared in a volume edited by Marco Buti, Servaas Deroose, Vitor Gaspar and João Nogueira Martins and was entitled "The Euro: The First Decade". ${ }^{2}$ That volume was the outcome of a conference held in October 2007, a meeting designed to celebrate the quality of economic policy-making within the Eurozone. It was hoped that the proceedings of that conference would be published with a fanfare in 2009, ten years after the birth of the Euro. Unfortunately, publishing delays meant that the volume only appeared in February 2010, barely three months before the eruption of the Greek crisis. The Allsopp-Vines paper, warning of difficulties with the SGP and advocating that it be radically reformed, appeared alongside a number of other papers, most of which painted a rosy picture of the Eurozone. With fitting irony, our article appeared as Chapter 13 in the volume.

The present contribution first sets out the conventional wisdom on European macroeconomic policy-making. It then describes the conventional views about what has gone wrong and of what to do next, and points out the weaknesses of

1 See Westaway, P.: Modelling Shocks and Adjustment Mechanisms in EMU, London, 2003. This paper was published by the UK Treasury in support of the UK's decision not to join EMU. The other analytical reason for the UK not to join EMU was the "Walters Critique", which is discussed below. There were of course also political reasons for the UK's decision.

2 Cf. Allsopp, C./Vines, D.: Fiscal Policy, Intercountry Adjustment and the Real Exchange Rate, in: Buti, M. et al. (eds.): The Euro: The First Decade, Cambridge, 2010; initially published in European Commission: EMU@10: Successes and Challenges after Ten Years of Economic and Monetary Union, in: European Economy, 2008. The proposal is set out less formally in Allsopp, C./Vines, D.: Fiscal Policy, Labour Markets, and the Difficulties of Intercountry Adjustment within EMU, in Cobham, D. (ed.): The Travails of the Eurozone, London, 2007. Earlier versions of the proposal may be found in Allsopp, C./Vines, D.: The Macroeconomic Role of Fiscal Policy, in: Oxford Review of Economic Policy, 2005; Allsopp, C./Vines, D.: Macroeconomic Policy after EMU, in: Oxford Review of Economic Policy 14/3 (1998), 1-23; and Allsopp, C./Vines, D.: Fiscal Policy and EMU, in: National Institute Economic Review, 158 (1996). A micro-founded model of this policy system is set out analytically in Kirsanova, T./Satchi, M./Vines, D./Wren-Lewis, S.: Optimal Fiscal Policy Rules in a Monetary Union, in: Journal of Money, Credit and Banking, 39/7 (2007), 1759-1784. In that paper, a fully calibrated model of the system is simulated to examine its robustness. Related ideas are carefully explored in European Commission: Adjustment Dynamics in the Euro Area: Experiences and Challenges, in: European Economy, 2006, although the authors of the latter contribution probably reached too optimistic a conclusion. 
these views. The main part of the article describes how the SGP could be replaced by the new Allsopp-Vines, stability-oriented, fiscal policy framework, directed towards correcting external imbalances within the Eurozone.

\section{The Conventional Wisdom}

Macroeconomic policy-making in the Eurozone was based on four very clear ideas:

\section{Monetary Policy}

Monetary policy was assigned the task of managing aggregate demand within Europe as a whole. This was to be carried out by the ECB, operating an inflation targeting regime for the Eurozone. The ECB would do this in a rules-based way, other than in exceptional circumstances: it would raise the interest rate when inflation was excessive and vice versa, perhaps even following an explicit feedback procedure of a Taylor Rule kind. Such an "assignment" of a particular instrument - the interest rate - to a particular target - the rate of inflation - would lead to a setup in which fiscal policy did not play a significant part in the management of the European economy as a whole. An arrangement of this kind very different from what might have been contemplated in the 1950s or 1960s was conventional by the time that EMU was established. This kind of approach was recommended by neo-Keynesian macroeconomics; it is set out in the classic textbook by Woodford. ${ }^{3}$ An arrangement of this kind had already been implemented in both the US and the UK. Thanks to an important "two-for-one" possibility. ${ }^{4}$ Such a system was one in which, subject to inflation being under control, the interest rate could be used to regulate aggregate demand in the European economy as a whole, so that it could operate at a close to full employment.

\section{Fiscal Policy}

Fiscal policy was assigned the task of stabilising public debt, something which had been severely out of control in Europe in the 1980s and 1990s. Article 104c [Article 126 TFEU] of the Maastricht Treaty stipulated that public deficits were

3 Woodford, M.: Interest and Prices: Foundations of a Theory of Monetary Policy. Princeton, Princeton University Press, 2003.

4 This two-for-one possibility results from the fact that the trade-off between inflation and unemployment is only a short run trade-off. See Alesina, A., O. Blanchard, J. Gali, F. Giavazzi, and H. Uhlig: Defining a Macroeconomic Framework for the Euro Area, London, CEPR, 2001 
not to exceed $3 \%$ of GDP, except in exceptional circumstances, and that public debt was to be gradually brought down towards a target level of $60 \%$ of GDP. ${ }^{5}$ In 1997 there was a further agreement, based on a proposal by the German Government, to reinforce the fiscal provisions of Article 104c. The Stability and Growth Pact, as this agreement came to be called, provided a commitment by EMU countries "to respect the medium-term budgetary objective of positions close to balance or in surplus". 6

\section{Wage and Price Setting}

Wage bargaining and price setting would be conducted with an understanding, by the players, of the discipline which had been imposed on them by their membership of a monetary union. This understanding also involved an assignment of responsibilities; wages and prices in each country should - it was asserted - be set in the knowledge that the country needed to remain appropriately competitive, relative to the other members of the union, so as to prevent the emergence of inter-country imbalances. Otmar Issing articulated how this system was meant to work in an important paper published in $2006 .{ }^{7}$ It was also suggested that the Lisbon process might play a part in helping the necessary behaviour to emerge; it was thought that this process might help bring pressure on uncompetitive regions to adjust their costs and prices in the appropriate manner (although it was never made clear how this might happen relatively more in some countries than in others, in whatever way was required).

5 This Article demanded that "Member States...avoid excessive government deficits". It called upon the "Commission [to] monitor the development of the budgetary situation and of the stock of government debt in the Member States with a view to identifying gross errors", i.e. substantial excesses over "reference values" (3\% of GDP for the deficit and $60 \%$ for the debt) specified in the protocol on the excessive deficit procedure annexed to the treaty (emphasis added). The reference values did not amount to "binding rules" in the sense that their breaching would lead to automatic sanctions. Nonetheless, Article 104c foresaw that the Council could eventually impose sanctions if a Member State persisted in failing to correct its situation.

6 This would allow EMU countries to deal with normal cyclical fluctuations while keeping their government deficit below the reference value of $3 \%$ of GDP. In essence, the SGP was designed to transform the $3 \%$ reference value specified in the treaty, which remained untouched, into a hard ceiling.

7 Issing, O.: The Euro: A Currency without a State, in: BIS Review 23, Bank for International Settlement: Basel, 2006. 


\section{The Financial System}

The creation of the Euro would mean that the financial integration brought about by the Single European Market could be carried much further, leading to a much more integrated, much more competitive, European financial system. It was understood that this would have a number of consequences. First, interest rates in the different countries in the union would converge. This would happen, it was believed, both (i) because of the absence of currency risk for the separate countries with the Eurozone, and (ii) because - given that sovereign states were bound by the Stability and Growth Pact - there would be no default risk for the separate sovereigns within the Eurozone. In such a stable European financial system, financial regulation could remain safely delegated to the separate nation states. The authorities in each of nation state would manage financial supervision. They would also provide lender-of-last resort financing to banks headquartered within their country, as and when this proved necessary.

\section{A Conventional View of What went Wrong and of What to Do About It}

\section{Monetary Policy}

Macroeconomic management of Europe as a whole by the ECB has been admirably successful, both in the period before the Global Financial Crisis (GFC), and during the early stages of the crisis, when interest rates were cut to very low levels to help mitigate the downturn, and when liquidity was injected as needed. The inflation-targeting strategy of the ECB remains firmly in place, and I believe that this should continue to be the case.

\section{Fiscal Policy}

In the exceptional circumstances of the GFC, all observers were glad that initial policy response was one in which the SGP was over-ridden. The very large fiscal deficits which emerged were caused both by discretionary policy actions, and, more importantly, by allowing the automatic stabilisers to operate.

However, before the crisis, the SGP was very significantly disregarded both by France and by Germany, and by high-debt countries such as Italy. Here is how Sapir describes what happened: ${ }^{8}$

8 Sapir, A.: Europe after the Crisis: Less or More Role for Nation States?, in: Oxford Review of Economic Policy, 2012 (forthcoming). 
"The cruel reality is that the essence of the SGP was never either fully understood or correctly implemented, with devastating consequences for countries that entered the monetary union with high debt levels. These countries were simply not made "to respect the medium-term budgetary objective of positions close to balance or in surplus", which would have reduced their debt levels. Greece was not alone in this situation, though it was admittedly the worst offender."

The new European Policy Semester is designed to re-establish the discipline of the SGP, so that public deficits move back to SGP-consistent levels, and so that stronger pressure is brought to bear to prevent violations of the SGP from happening again, in non-crisis times. As discussed below, I believe this objective to be profoundly misconceived.

\section{Wage and Price Setting}

The adjustment of competitiveness within Europe has clearly not happened in the way which was designed. As Sapir writes: ${ }^{9}$

“....there was ... a failure to ensure... sustained convergence of the economic performances of the Member States. As the European Commission (2008) recognized in its assessment after 10 years of EMU, 'there have been substantial and lasting differences across countries in terms of inflation and unit labour costs. The tendency for persistent divergences between euro-area Member States has been due in part to a lack of responsiveness of prices and wages, which have not adjusted smoothly across products, sectors and regions. This has led to accumulated competitiveness losses and large external imbalances'.... Greece was not alone in this situation, but it was probably the worst case."

The Competitiveness Strategy within the European Policy Semester is designed to reinforce such pressure. But it is not clear what policy instruments this European Policy Semester seeks to use to bring about adjustment in an appropriate way. At present, the Competitiveness Strategy within the European Policy Semester is an "Emperor with No Clothes". As noted above, the Lisbon process has not achieved this objective in the past. But now even the Lisbon process is dead. 


\section{The Financial System}

The understandings of what would happen financially within the Eurozone, following greater financial integration within Europe, were initially correct. But these understandings have disintegrated - in an incredibly dangerous way - under the pressure of the European sovereign debt crisis. The re-emergence of currency risk has created vulnerability in the banking systems of many peripheral countries. And the emergence of default risk for peripheral sovereigns has raised the interest rates which these sovereigns must pay, worsening their default risk in a vicious circle. Furthermore this sovereign default risk is increasing the vulnerability of banking systems, because European banks hold so much European sovereign debt. A self-fulfilling bad outcome is now a distinct possibility.

It is important to be clear that this looming financial instability is a direct consequence of the inability of the Stability and Growth Pact to appropriately manage fiscal deficits within the Eurozone, and of the related difficulty of adjusting competitiveness within the Eurozone. The financial instability which has emerged within the Eurozone is not just a consequence of financial mismanagement. It is a direct consequence of the failure of the European fiscal framework. That is why it is so urgently necessary to replace the SGP.

\section{A New European Macroeconomic Policy Framework}

\section{A New Fiscal System}

I now present the Allsopp-Vines alternative to the SGP, first describing in greater detail the damage which has been done by the Pact.

First, the countries of the European periphery, in particular, Spain and Ireland, experienced excessive growth in domestic demand in the period 2001 to 2008. Furthermore, this excessive demand was self-reinforcing. It caused an increase in inflation, relative to the European average, but since these countries necessarily faced the same interest rate as other countries within EMU, the increase in demand was not met by higher nominal interest rates, and the result was therefore lower real interest rates, something which exacerbated the excess demand. This kind of problem within a monetary union has been called "The Walters' Critique", after Sir Alan Walters, the economic adviser to Prime Minister Margaret Thatcher, who was critical of the European Monetary System in the 1980s along these lines. Widespread understanding within the UK of this Walters-critique problem was the second analytical reason why the United Kingdom refused to 
join the EMU. The SGP did not discipline these surges in demand; on the contrary, it reinforced them.

Second, it is clear that the Stability and Growth Pact encouraged Germany to maintain aggregate demand at an inadequate level for a number of years. This meant that German costs continued to fall relative to those in the rest of Europe for a full ten years after the creation of EMU, causing German competitiveness to increase remorselessly, relative to the position of other countries within the Union. This was an important counterpart of the development of the imbalances within the Eurozone.

Allsopp and I suggest that, within the Eurozone, a country's fiscal policy should be conducted not with reference to the size of the country's public debt, but with reference to the country's external position. ${ }^{10}$ If this approach was adopted, countries in external deficit would be required to undertake contractionary fiscal policy, as has been required by the SGP for countries in the European periphery at present. But there would be six important additional features of such a policy, compared with the fiscal policy regime which is operating at present in the Eurozone.

First, this would be would be a rules-based policy requiring that, except in exceptional circumstances, fiscal policy should follow feedback rules which relate the required budgetary position to the external position of the economy. The response of fiscal policy would be that of "graduated feedback"- the worse the external position the greater the fiscal adjustment which would be required. There is a contrast here with the on-off way in which the SGP has been applied with deficits allowed up to a level of $3 \%$ of GDP and then not allowed. So the criticism of the SGP is not just that it has been assigned the wrong task - that of stabilising public debt - but that it has attempted to do this in a binary manner.

Second, our proposed policy would respond to external imbalances caused by private sector behaviour, not just to external deficits caused by the public sector. This is something which the SGP did not do. It is clear, as Sapir says, that Greece disobeyed the SGP rules. But Ireland and Spain did not do this - indeed they ran fiscal surpluses - and yet excessive private expenditure in both of these countries, financed by bank loans, led to excessive private-sector demand and to external deficits. Fiscal policy should have been able to act against this, and

10 This means external position vis-à-vis other European economies. Such a strategy would not use fiscal policy to target the imbalance of the Eurozone vis-à-vis the rest of the world. 
should have been required to do so, but this did not happen. Similarly, the combination of the high private savings in Germany, compared with a cautious fiscal position in that country, has led to an excessive German surplus within Europe. Fiscal policy should have been able to act against such behaviour by Germany, and should have been required to do so, but that did not happen either.

Third, a fiscal strategy concerned with rectifying external imbalances would ensure a sustainable outcome for a country's public debt, without the fiscal policy of the country being actually assigned to the control of public debt. This is the case for the following reason: countries in uncompetitive positions, relative to other countries within Europe, have depressed net exports, and so tend to have low levels of economic activity as well as low levels of fiscal revenue, as in the European periphery at present, and in Italy. An Allsopp-Vines fiscal strategy would require a tightening of the fiscal position in these countries in response to their external difficulty. This fiscal tightening would cause the public-sector deficit to move in the right direction - and so ensure that public debt remained under control - at the same time that it reduced the overall level of domestic spending in the economy and so caused the external deficit of the economy to move in the right direction. And such fiscal action would - through the lower demand which it created - bring about longer-term downward pressure on costs and prices. That would, of itself, tend to improve exports, and so raise the level of economic activity and fiscal revenue, meaning that the fiscal discipline could gradually be somewhat relaxed over time. All of the above is true, in reverse, for excessively competitive countries, in positions of external surplus, such as is the case for Germany at present. Thus a fiscal policy designed to rectify an external position due to an inappropriate level of competitiveness in the economy would, of itself, create movements in the public sector deficit which would be selfcorrecting and so would ensure that the fiscal position was sustainable. Note that such a fiscal-policy system is very different from one which would use a fiscal deficit to stabilise the output gap in a country in these circumstances. ${ }^{11}$

11 Some analysts have mistakenly suggested that, in the absence of any problems with inflation in a country within EMU, its fiscal policy could attempt to stabilise its output gap. This is thought to be a good idea, presumably by analogy with what monetary policy does in a well-designed inflation-targeting regime. In such a regime, in the absence of any inflation problem, monetary policy seeks to stabilise the output gap. But a recommendation that fiscal policy be used in an analogous way within EMU risks advocating a profoundly irresponsible fiscal policy, in the case we are considering in which the downturn in demand is due to the inadequate competitiveness of the economy. It would in damp, or indeed prevent, the operation of the adjustment process which I have described above. See H. M Treasury: Fiscal Stabilisation and EMU: a Discussion Paper. London, 2003. 
Fourth, this fiscal strategy would have its own "two-for-one" feature analogous to the feature described above for monetary policy. Consider the situation discussed in the previous paragraph in which external difficulties caused by problems with competitiveness are dealt with by the fiscal strategy. Then, subject to this, a fiscal policy concerned with rectifying external imbalances would ensure a moderating outcome for a country's fiscal deficit in response to tendencies towards external imbalance that were caused by the behaviour of the domestic private sector. That is to say, this kind of fiscal-policy strategy would tend to moderate the effects of that private sector behaviour. Thus an excessive level domestic expenditure, like that which occurred through the construction of houses in Spain and Ireland, would - because these expenditures cause an external imbalance - have led to a tightening of fiscal policy. Similarly, a high level of private savings, as in Germany as at present, would require a loosening of the fiscal position. That is, it would require the use of the public balance sheet to support overall spending when private balance sheets are being rebuilt and private sector spending is inadequate.

Fifth, our proposed policy regime would be able to deal with the problems raised in the Walters critique. Kirsanova et al. describe in detail how a rules-based fiscal policy, designed to correct external imbalances could be made to operate in response to the loss of competitiveness. ${ }^{12}$ A country in this position, experiencing a reduction in net exports, would be required to move fiscal policy sharply in a contractionary direction, when the external difficulty was first observed, speeding the downward pressure on costs and prices. But as the competitiveness of the economy adjusted, the fiscal rule would be deliberately loosened to prevent the kind of overshoot of costs and competitiveness which has happened within Europe over the last decade. Since the adjustment of costs and prices is lagged, so that inflation is subject to persistence, this policy would need to be carefully forward-looking, ensuring that the adjustments in wages and prices which were underway would gradually bring the economy to the right level of competitiveness.

Sixth, this overall policy would apply symmetrically to surplus countries as well as to deficit countries, avoiding the situation at present in which adjustment is forced upon the countries that are facing difficulties in competitiveness, which at present - means countries in the European periphery. 
The alternative policy we propose would require discretion, in comparison to the mindless application of simple rules that has characterised the attempt to implement the SGP. In particular, the strategy for dealing with the Walters critique which I have described above would require policymakers to use the fiscal position to influence the development of costs and prices, so as to steer the real exchange rate of the economy towards the level which was expected to be appropriate in a few years' time. Decisions of this kind would not only require the ability to look ahead. They would also need to be managed on a Europe-wide basis to avoid countries seeking inappropriate competitive advantages at the expense of each other. As a result such a policy strategy would need to be managed by national fiscal councils, bodies of the kind which have been advocated by many observers. The design of such fiscal councils would be a major task, since they would need to operate in a transparent, credible and internationally consistent manner.

\section{Wage and Price Setting within the New European Macroeconomic Policy Framework}

The policy system advocated by Allsopp and Vines - using a fiscal policy directed towards external competitiveness - would bring fiscal pressure to bear on the relative adjustment of costs and princes where that was necessary. Notwithstanding this fact, the required adjustments of wages and prices are exceptionally difficult to bring about within a monetary union; real exchange rate changes are much harder to change than is the case in a world of floating exchange rates. In that latter case the currency can simply be devalued. And these adjustments are particularly difficult to achieve in a downward direction. The recent success of Ireland in doing this mainly serves to show how difficult this problem is.

The introduction of the kind of fiscal policy described above would, of course, make clear to wage and price setters the way in which their behaviour would need to be disciplined so that the country's competitive position could be adjusted in whatever way was required to correct the country's external imbalances. There is an analogy here with the way in which the introduction of inflation targeting made it clear to wage and price setters how their behaviour would need to be disciplined so that it fell within the confines established by the inflation target. In a similar manner here, the more that those who set wages and prices became aware of any policy objective of adjusting competitiveness, the more they would tend to carry out this adjustment themselves, and the less active would fiscal policy need to be in order to induce the necessary adjustments. Such 
a system would therefore, if well implemented, have a self-reinforcing aspect, in exactly the same way that inflation-targeting regimes have come to possess such an aspect.

The necessary adjustment of wages and prices would be assisted in those countries where direct pressure could be bought on the fixing of wages and prices through institutional and political means. And in cases where competitiveness gets significantly out of line, as in Greece at present, there may be no alternative to a major political intervention designed to bring about an across-the board cut in wages of a very large amount. It may not be possible to effectuate the necessary "internal devaluation" by any other means.

\section{The Financial System within the New European Macroeconomic Policy Framework}

Many observers are currently discussing the policy issues related to financial policy, sovereign risk, and the fragility of the European banking system. There is now a great degree of vulnerability in the banking system, both on the periphery - in particular in Greece and Spain - and in northern Europe, because banks in the North hold significant quantities of Southern debt. This is leading directly to further increases in sovereign risk premia, because lender-of-last resort obligations remain located with the separate member states and are not centrally shared. After much regrettably public controversy it has been agreed that the ECB will stand behind the debt of peripheral sovereigns, and that it will provide liquidity support for the banking systems in peripheral countries. The EFSF is to stand behind these obligations of the ECB, bearing at least some of the balancesheet risk which has up until now fallen on the ECB.

But three things have not yet been decided. First, it has not yet been agreed who will bear the balance-sheet consequences of the necessary write-downs of Greek debt, and possibly the write-downs of the debt of other peripheral sovereigns. Second, it is not yet clear who will bear the burdens of recapitalising the Northern European banks, which hold large amounts of the now more risky debt of the peripheral sovereigns. And third, it has not yet been decided which fiscal authorities in Europe will stand behind the lender-of-last-resort functions of the ECB. Political decisions on these three matters need to be taken exceptionally quickly. All of these three things fundamentally involve the difficult question of who takes the rap when this financial system experiences a crisis. The very high risk premia affecting many peripheral European sovereigns show that many market 
participants now believe that the difficult decision - about who bears this burden - will not be taken fast enough to avoid outright catastrophe. Let us hope that these participants are wrong.

But a rapid decision on these three matters alone will not be sufficient to end the Eurozone crisis. Something else is needed as well.

The fundamental reason why the Eurozone got into such a mess is - I have argued - because the necessary macroeconomic adjustments did not take place between the periphery and the northern part of Europe. Thus, I have argued, the mess did not arise because of a failure to enforce the Stability and Growth Pact. And it did not arise primarily because of a failure to adequately regulate the European financial system. The Eurozone crisis has arisen because there was no satisfactory framework for macroeconomic policy within the EMU. I have argued that such a framework would have used fiscal policy to force the periphery to adjust its uncompetitive position in an appropriate way. And it would also have required that Germany adjust its excessively competitive position appropriately. It is this failure to adjust which has brought about the Eurozone crisis, and the SGP helped cause this failure to adjust. Only when a framework is put in place that causes the required adjustments to take place on an on-going basis, will a sustainable recovery from crisis be possible for the Eurozone. And only then will it be possible to re-establish a properly functioning financial system within the Eurozone.

When, and only when, this happens, the Eurozone will be able to move again to a position in which all sovereign debt within the zone can be issued with some form of collective guarantee, so that no sovereign debt carries its own particular sovereign risk premium. This will take Europe back to its position before 2007, a position which it is necessary to re-establish, in order to avoid the cumulative instabilities which I have described above.

Many have argued that we need to move in the opposite direction, towards a world in which sovereigns in difficulty are disciplined by the existence of sovereign risk premia. I believe that this would be a spectacular mistake. The proposal discussed above deliberately points in the opposite direction, towards a fiscal framework in which fiscal positions are managed so as to prevent imbalances emerging within the Eurozone, and so as to ensure, as a corollary, that there are sustainable fiscal positions within the Eurozone. In such circumstances - but only in such circumstances - it is appropriate for sovereign risk within Europe to be collectively shared, so that there are no sovereign risk premia applying to the 
separate sovereigns. And only in such circumstances is it appropriate that the lender-of-last-resort facilities provided by the ECB are given a fiscal backup which is provided collectively.

\section{Conclusion}

This short contribution has argued for a very significant reconfiguration of European fiscal policy. Within EMU, a natural way for economies to adjust to asymmetric shocks is through changes in competitiveness. But, in a world of wage rigidities and capital market imperfections, this process needs to be managed by fiscal policy. I have argued that, without such fiscal management of the response of countries to asymmetric shocks, the new European Policy Semester is doomed to failure.

Obviously, the framework which I propose is one in which there is a clear commitment to ensuring that all of the existing members of EMU remain within the monetary union. It is time to abandon loose talk about the possibility of Greece, and of other countries in the periphery, being ejected from EMU. It is even more definitely time to abandon so-called serious, so-called careful, talk about whether "it might be appropriate for peripheral countries to consider leaving the Eurozone". Such talk is incredibly dangerous: it puts the future of the world economy at risk. 